\title{
ASSESSMENT OF THE DETERIORATION DEGREE OF AIRFIELD PAVEMENT FUNCTIONAL CONSTITUENTS MADE OF CEMENT CONCRETE
}

\section{OCENA STOPNIA ZDEGRADOWANIA NAWIERZCHNII ELEMENTÓW FUNKCJONALNYCH LOTNISK WYKONANYCH Z BETONU CEMENTOWEGO}

\author{
Piotr Barszcz, Mariusz Wesołowski
}

\author{
Air Force Institute of Technology \\ piotr.barszcz@itwl.pl; mariusz.wesolowski@itwl.pl
}

\begin{abstract}
The characteristic feature of the approach to the analysis of the airfield pavement deterioration degree as outlined in this paper is the fact that not only existing deteriorations are taken into account of but also already completed historical repairs. This approach enables determination of resources needed to conduct repairs and setting up reasonable schedules of future overhauls. The proposed index of the pavement deterioration degree, calculated on the basis of measured deficiencies and past repairs, makes it possible to assess the technical condition of the airfield pavement in a comprehensive manner. The key information indispensable to evaluate the degree of deterioration of the airfield pavement surface includes data which can be acquired from already completed stocktaking inventories. The stocktaking process is based on the catalogue of deficiencies typical for airfield pavements and the rules for stocktaking measurements.
\end{abstract}

Keywords: index of the airfield pavement deterioration degree, stocktaking inventory

Streszczenie: Charakterystyczna cecha zaprezentowanego $w$ artykule podejścia do analizy stopnia zdegradowania nawierzchni lotniskowych jest to, że do oceny brane sa pod uwage zarówno istniejace uszkodzenia jak $i$ wykonane naprawy. Takie podejście pozwala na określenie niezbędnych zasobów potrzebnych do przeprowadzenia napraw i racjonalne zaplanowanie remontów. Zaproponowany wskaźnik oceny stopnia zdegradowania, obliczany $w$ oparciu o obmiarowane uszkodzenia i naprawy, pozwala na całościowa ocene stanu technicznego badanej nawierzchni. Podstawowa informacja, jaka jest niezbędna do przeprowadzenia oceny stopnia zdegradowania nawierzchni jest pozyskanie danych z przeprowadzonej inwentaryzacji. Inwentaryzacje prowadzi się $w$ oparciu o katalog typowych uszkodzeń nawierzchni i zasady prowadzenia obmiaru.

Stowa kluczowe: wskaźnik oceny stopnia zdegradowania nawierzchni lotniskowej 
Assessment of the deterioration degree of airfield pavement functional... Ocena stopnia zdegradowania nawierzchnii elementów funkcjonalnych lotnisk...

\section{Introduction}

The characteristic feature of the approach to the analysis of the airfield pavement deterioration degree as outlined in this paper is the fact that both existing deteriorations are taken into account and historical repairs that have been completed up to the specific day. It is an approach which enables determination of resources needed to conduct repairs and setting up reasonable schedules of future overhauls. The proposed index of the pavement deterioration degree, calculated on the basis of measured deficiencies and past repairs, makes it possible to assess the technical condition of the airfield pavement in a comprehensive manner. The key information indispensable to evaluate the degree of deterioration of the airfield pavement surface includes data which can be acquired from already completed stocktaking inventories. The stocktaking process is based on the catalogue of deficiencies typical for airfield pavements and the rules for stocktaking measurements. Other factors assisting the stocktaking process are the inventory of typical deficiencies and repair procedures as well as the list of standardized parameters with their units of measurements. The acquired information about existing deficiencies and past repairs makes it possible to establish the degree of the airfield pavement damage and to define assessment criteria. One has to note that the assessment limited to merely visual inspection is quite difficult regardless the seeming simplicity, therefore the stocktaking process must be standardized.

\section{Stocktaking process}

The stocktaking process includes all efforts intended to provide a detailed "as-is" description of the constituents which define the feature subjected to assessment according to its status on a specific day. The inventory of existing deficiencies and historical repairs of pavements on functional components of airfields (EFL) is kept in line with the adopted assumptions and with the use of already prepared blanks and checklists. The stocktaking process consists in inspection of the basic component, which is the airfield apron (the sample). Deficiencies revealed during the inspection and information on already completed repairs are marked on standardized blanks with the use of commonly used symbols. For the stocktaking process, the general practice was adopted that detected deficiencies are marked in red and already repaired flaws are marked in black (Fig. 1). Markings are made on the blanks with the figures and notes which describe specific types of flaws and completed repairs.

According to the adopted nomenclature, the set of parameters which reflect the deterioration degree of the airfield apron includes (Fig. 1).

- deep and shallow spalling and flaking;

- fissures, cracks and gaps caused by freezing,

- cement rock splinters,

- breaks, spalls of edges and corners,

- deep cavities, 
- foreign materials in gaps,

- misalignment of slab surfaces,

- drills,

- concrete slabs in need of replacement.

One of the most functional components of airfields are runways, thus the maintenance standards which apply to these constituents are more demanding than those of taxing roads or parking aprons. Loose particles detached from runway pavements may cause damage of aircraft engines and airscrews. Safety rules for operation of aircrafts enforce the need to carry out stocktaking of runways on a continuous basis, where the runway pavement is considered the key constituent subject to frequent inspections. In the case of other functional constituents of airfields, such as parking aprons or taxing roads, investigation of pavements can be carried out upon analysis of several samples taken from the section of interest, however attention should be paid whether aircrafts perform taxing operations with the use of own engine or are hauled on the airfield section under tests. When the specific functional constituent of the airfield is not crucial for operation of an aircraft, the number of samples to be taken for investigation can be defined by means of the formula below:

where:

$$
n=\frac{N s^{2}}{\left(e^{2} / 4\right)(N-1)+s^{2}}
$$

$\mathrm{N}$ - total number of samples to be taken from the airfield area under test,

e - permissible error for estimation of the $D$ factor which defines the deterioration degree of the airfield area under test,

s - standard deviation of the $D$ factor between samples to be taken from the airfield area under test.

It is recommended to deploy the sampling locations within uniform spacing down the whole section of the area under test and the first sampling location should be selected randomly. This technique is commonly known as "systematic sampling". For comprehensive assessment of the entire area under tests, the samples that are taken for investigations should be representative, not random ones. The main goal of the process of evaluating expenses due to maintaining airfield pavements in sound technical condition and assessing their technical condition is to obtain reliable information at cost-efficient expenditures, with consideration to aircraft operation safety. Table 1 comprises examples which explain how to define the number of samples for tests.

However, the systematic sampling approach applied to both the airfield design and the operation and maintenance phases has one substantial drawback, i.e. samples in very poor condition shall not be covered by the tests. On the other hand, the samples with some multiple flaws (e.g. longitudinal and crosswise throughout cracks of pavement slabs) may be incorrectly classified as random ones. 
Assessment of the deterioration degree of airfield pavement functional... Ocena stopnia zdegradowania nawierzchnii elementów funkcjonalnych lotnisk...

To standardize the stocktaking process with the uniform classification of flaws and interpretation of inspection results, the "Inventory of typical deficiencies and repair procedures of airfield pavements made of cement concrete" was prepared, as shown in Fig. 1.

Table 1. Selection of the number of samples qualified for tests with reference to the total number of samples collected on the area of investigation.

\begin{tabular}{|c|c|c|c|}
\hline $\begin{array}{c}\text { Number of samples } \\
\text { on the investigation } \\
\text { area (N) }\end{array}$ & $\begin{array}{c}\text { Number of samples } \\
\text { qualified for tests } \\
(\mathrm{n})\end{array}$ & $\begin{array}{c}\text { Number of samples } \\
\text { on the investigation } \\
\text { area (N) }\end{array}$ & $\begin{array}{c}\text { Number of samples } \\
\text { qualified for tests } \\
(\mathrm{n})\end{array}$ \\
\hline $1 \div 5$ & 1 & 1 & 1 \\
\hline $6 \div 10$ & 2 & $2 \div 4$ & 2 \\
\hline $11 \div 15$ & 3 & $5 \div 20$ & 3 \\
\hline $16 \div 40$ & 4 & $>20$ & 4 \\
\hline$>40$ & $10 \%$ & & \\
\hline
\end{tabular}

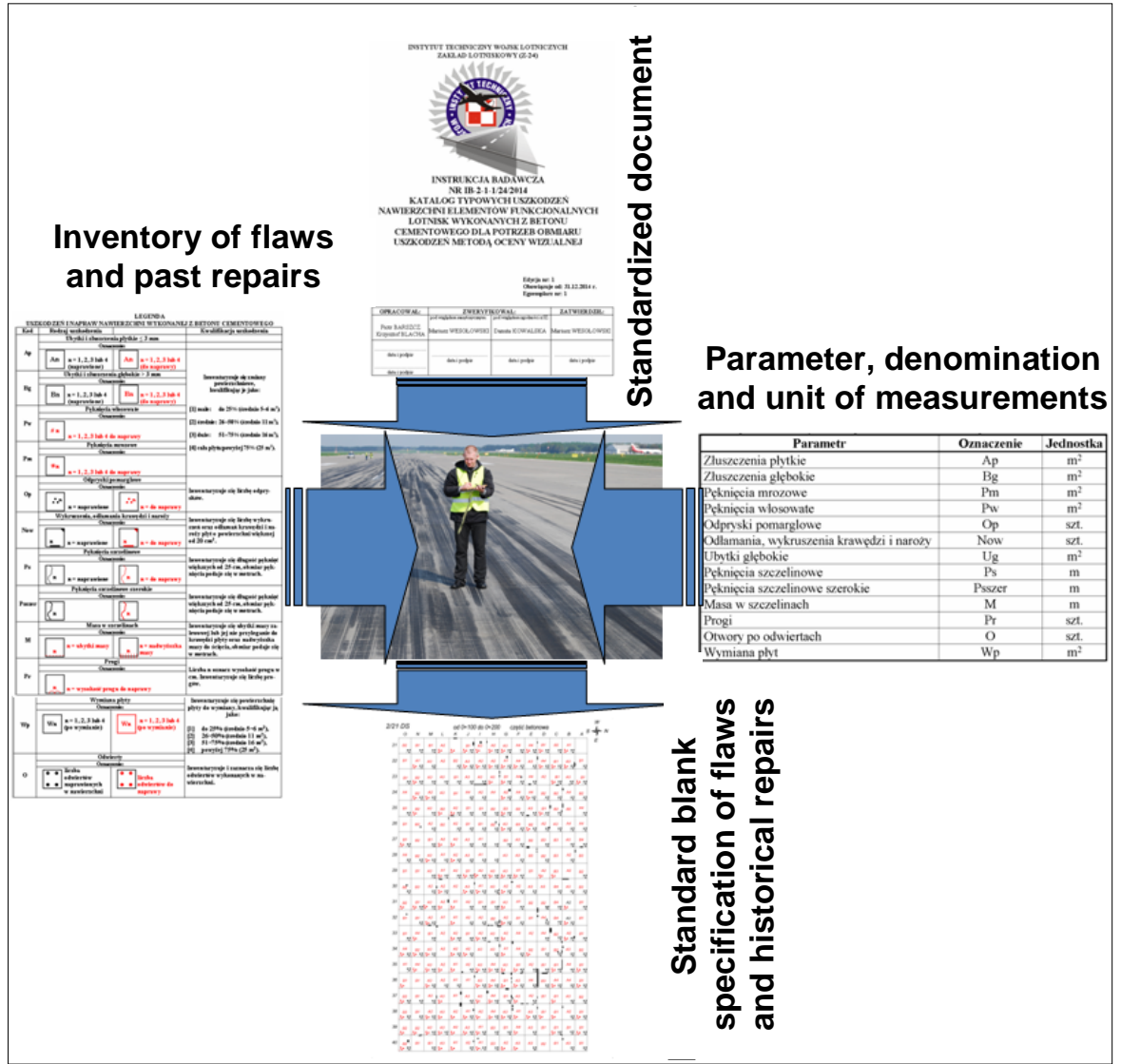

Fig. 1 Stocktaking of flaws and past repairs to be carried out by visual inspection by an expert engineer properly trained for these operations 


\section{Assignment of weight coefficients to factors that define condition of airfield pavements with use of the method of expert assessment}

The method enabling assignment of weight coefficient to parameters which are used to assess airfield pavements is the method of expert assessment. The weight coefficients were assigned to individual parameters in the five following steps:

1) Employment of five experts.

2) Development of the list with all factors which define the technical condition of airfield pavements.

3) Sequencing of the factors by their ranks of importance (e.g. deep spalling, cement rock splinters, fissure cracks, etc.).

4) Instructing the experts to assign appropriate weight coefficient to each factor with account of its impact on the technical condition of the airfield pavement upon completion of an inspection and with consideration to operational safety of aircrafts.

5) Summarizing of the investigation outcome.

The employed experts estimated the weight coefficients with the use of relationships known from mathematical statistics. The arithmetical mean for weight coefficients of each $i^{\text {th }}$ factor with consideration to opinions of all experts was calculated by the following formula:

$$
\bar{\varphi}(i)=\frac{\sum_{l}^{m} \varphi(i, j)}{n}
$$

where:

$n \quad$ - number of experts;

$\varphi(i, j)$ - weight coefficient for the $i^{\text {th }}$ factor;

$m$ - number of factors.

The average weight coefficient for the expert assessment:

$$
\varphi_{0}=\frac{\bar{\varphi}(i)}{\sum_{l}^{m} \varphi(j)}
$$

Dispersion of weight coefficient for the expert assessment:

$$
\delta_{i}^{2}=\frac{\sum_{l}^{m}[\varphi(i, j)-\bar{\varphi}(i)]}{m}
$$


Assessment of the deterioration degree of airfield pavement functional... Ocena stopnia zdegradowania nawierzchnii elementów funkcjonalnych lotnisk...

Fig. 2 presents the graph of weight coefficient dispersion for the expert assessment.

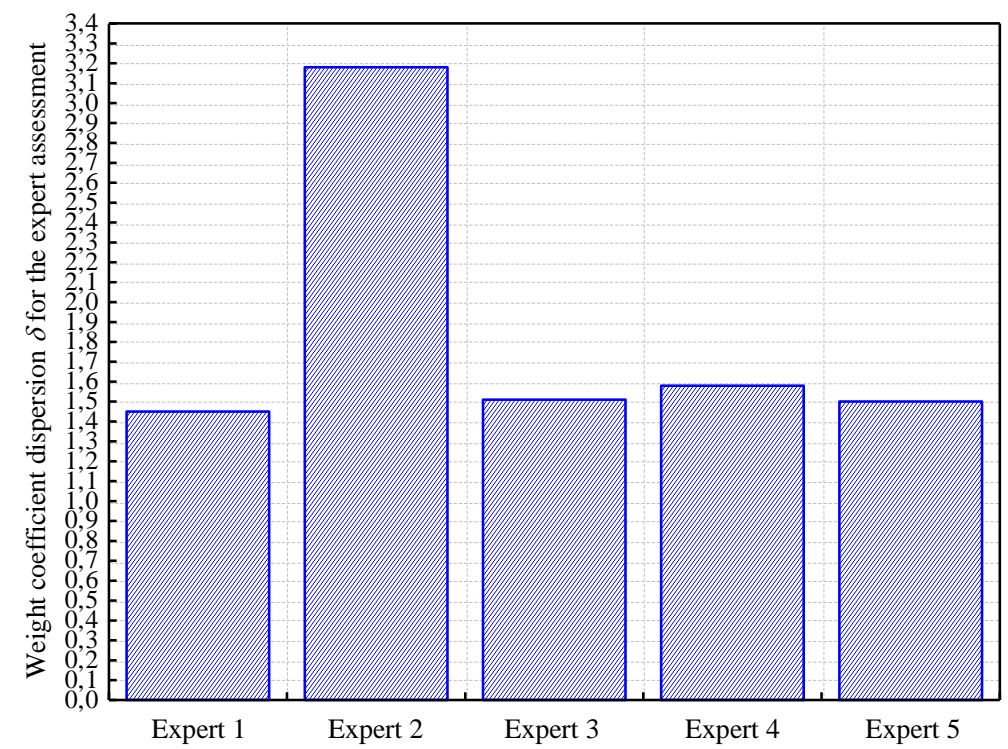

Fig. 2.The graph of weight coefficient dispersion for the expert assessment

Variance coefficient:

$$
\vartheta_{j}=\delta_{i} / \bar{\varphi}(i)
$$

Fig. 3 presents the graph for variance coefficients.

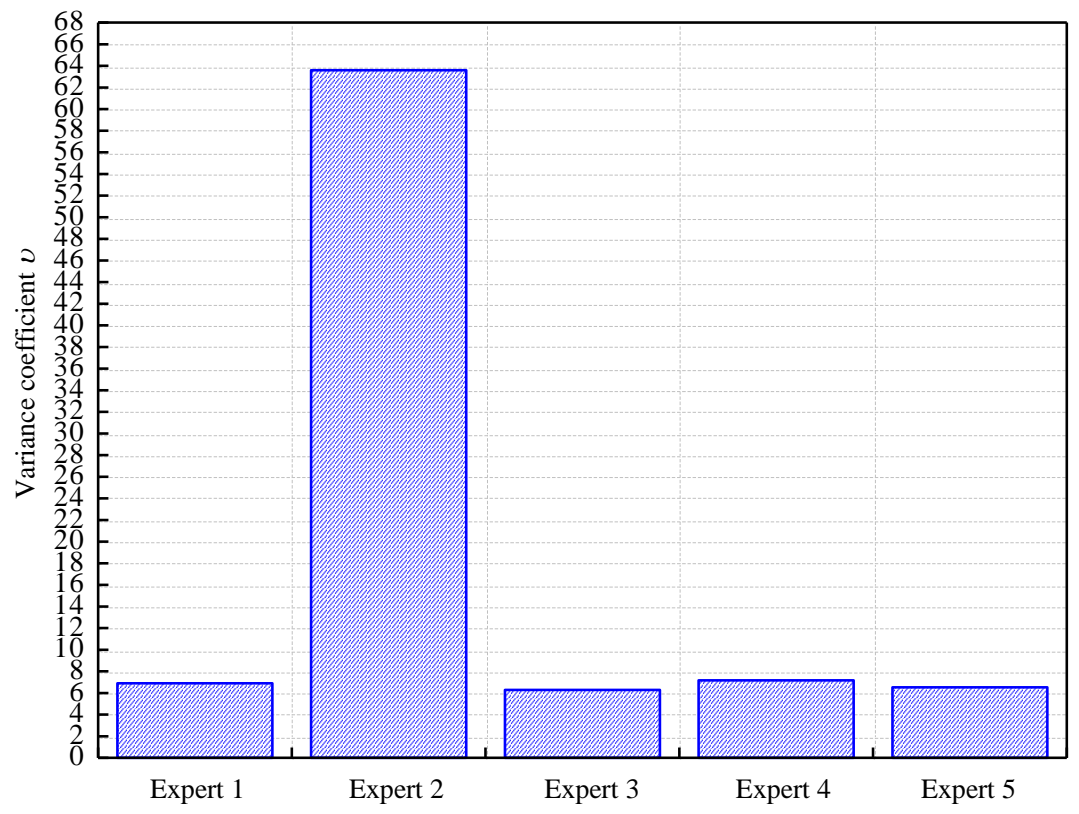

Fig. 3 The graph for variance coefficients 
The statistical dispersion and the variance coefficient convey the information on the degree to which the experts agree on the importance of each specific factor. The smaller the value of the variance coefficient, the more opinions of the experts are in conformity with regard to the importance of each specific factor. The average weight coefficient from expert assessments and the variance coefficient are considered as the criteria for proper assignment of weight coefficients.

\section{Estimation of the deterioration degree specific to functional constituents of airfields made of cement concrete}

Deterioration of the technical condition is a slow and long-lasting process. In general, it consists in worsening of structure properties due to impact of external factors, which eventually entails irreversible alterations of the structure. The deterioration degree of pavements on individual functional constituents of airfields is impacted by deficiencies (flaws) and historical repairs that have been completed in the past. Such a degree is determined on the basis of 13 predefined flaws or repairs. To achieve the best estimation of the factor which depicts the actual degree of the airfield pavement deterioration, it is possible to consider two options of calculations, where the assumptions are made that completed repairs contribute to deterioration of the airfield pavement in either $20 \%$ or $50 \%$. The average factor for assessment of deterioration degrees specific for functional constituents of airfields can be calculated according to the formula below on the basis of information acquired during the stocktaking process:

$$
\begin{gathered}
\overline{D_{B C}}=\frac{\sum_{i=1}^{13} D_{i}}{13} \\
\overline{D_{B C}}=\frac{\sum_{i=1}^{13} D_{i}}{w} \\
D_{i}=\left(\frac{w_{i}^{U} p_{i}^{U} O b_{i}^{U}+w_{i}^{N} p_{i}^{N} O b_{i}^{N}}{F}\right) 100=\left(W_{i}^{U}+W_{i}^{N}\right) 100
\end{gathered}
$$

where:

$D_{i}$ - deterioration of pavement on a specific functional airfield constituent made up of cement concrete with consideration of the $i^{\text {th }}$ parameter;

$p_{i}$ - conversion factor for the parameter that is characteristic for a specific flaw or repair to refer that factor to the entire area of damaged or already repaired locations

$w_{i}$ - statistic weight coefficient which defines importance of the parameter specific for the flaw or repaired area within the EFL system for assessment of the deterioration degree; 
Assessment of the deterioration degree of airfield pavement functional... Ocena stopnia zdegradowania nawierzchnii elementów funkcjonalnych lotnisk...

$O b_{i}$ - 'as-is' stocktaking of damaged or already repaired areas within the EFL system;

$F$ - overall area of the surface subjected to evaluation by means of the EFL system

Fig. 4 presents graphs for factors which depict the deterioration degree of airfield pavements and are calculated on the basis of the adopted methodology.

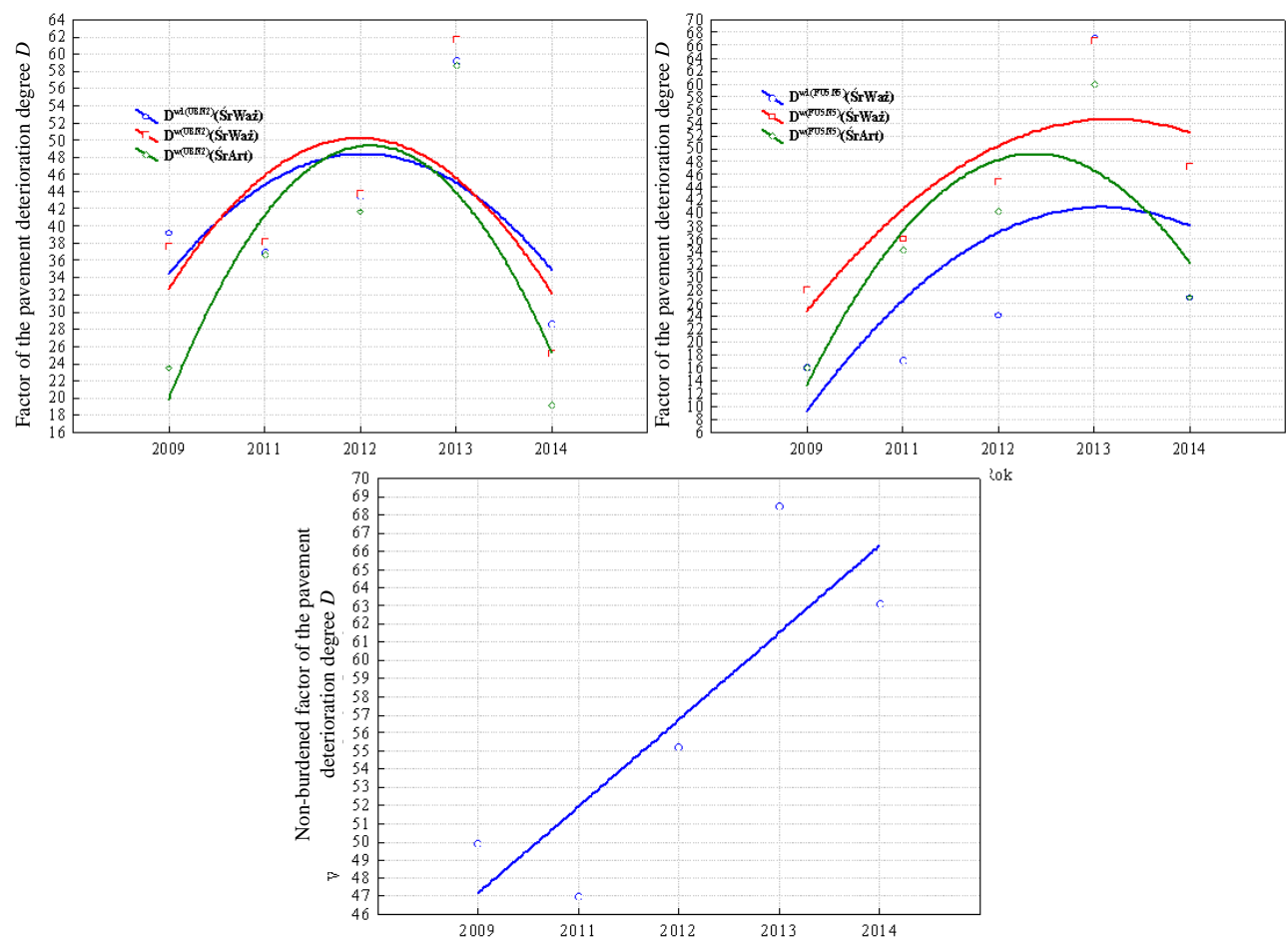

Fig. 4 Graphs to depict variations of the pavement deterioration degree for the airfield runway.

\section{Criteria for assessment of the deterioration degree specific for pavements of individual airfield constituents made of cement concrete}

The index which exhibits the deterioration degree of pavements on functional constituents of airfields ranges from 0 , which stands for the pavements in perfect operating condition, to 100 , which says that the pavement is no longer suitable for operation. Calculation of the $D$ index stems from the outcomes of visual inspections in which flaw types and past repairs with 'as-is' measurements of the affected areas are determined. The impact of flaw types and past repairs on the safety of aircraft operation is taken into account in calculations by assumption of weight coefficients estimated on the basis of expert opinions. 
Typically, the scale for assessment of the pavement deterioration degree comprises 7 grades, however the simplified scale with only 3 grades can be used as well, since it is sufficient to decide on suitability of a specific airfield constituent for further operation. Each grade is associated with classes which define the condition of pavements. The first grade represents the desirable (sound) condition which comprises new or renewed pavements with the assumptions that such pavements shall need no scheduled maintenance during the upcoming five years. The warning, i.e. intermediate grade says that condition of the pavement triggers the need to carry out detailed investigations to find out whether or not reconditioning measures for the pavement are necessary. The last grade corresponds to the critical condition when operational and technical investigations are really urgent to establish remedy measures to improve the condition of the airfield pavement. Fig. 5 depicts relationships between the decisive grades and classes of the pavement condition according to the EFL system. Specifications for pavement classes are summarized in Table 4. The critical threshold of the $D$ index means that the condition of the pavement rapidly decreases after that threshold is exceeded.

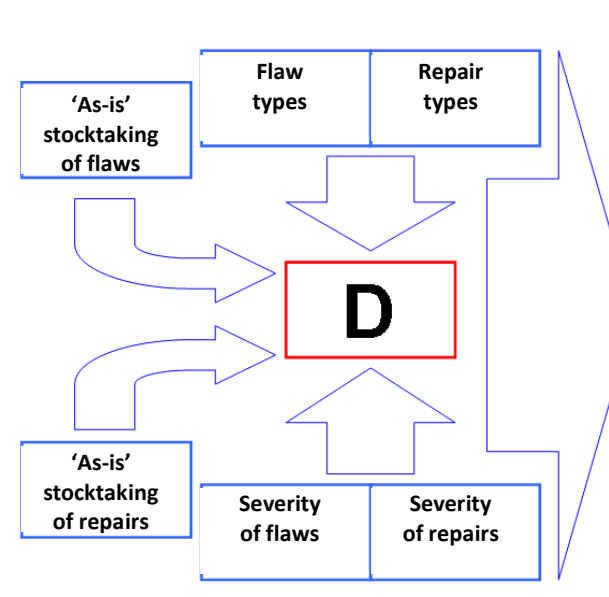

Fig. 5. Criteria for assessment of the pavement deterioration degree specific for functional constituents of airfields (EFL)

\section{Conclusions}

1) Verified parameters which define the deterioration degree of airfield pavements make it possible to predict and estimate the remaining period of safe operation for each specific functional constituent of the airfield, which finally enables triggering of maintenance operations for these constituents (EFL) according to their real condition.

2) The deterioration degree of airfield pavements is evaluated on the basis of assumed factors and importance of each factor is established as weight coefficients defined with the use of the method of expert assessment. 
Assessment of the deterioration degree of airfield pavement functional... Ocena stopnia zdegradowania nawierzchnii elementów funkcjonalnych lotnisk...

3) To predict the condition of an airfield pavement in a reliable manner, it is necessary to use a system for unbiased and repeatable assessment. Development of an IT system to support management of pavements on individual functional constituents (EFL) should be preceded by the analyses of processes that are in place at specific organizational units.

4) Assessment of the deterioration degree for a single concrete slab requires a different approach than the analysis of a functional constituent of an airfield. Therefore, it would be desirable to define appropriate parameters and indices which define the technical condition and the deterioration degree of slabs. The measurement results shall serve as the kick-off point to define evaluation criteria to establish whether a specific slab can be still in use with no hazard to the safety of aircrafts or whether it should be qualified to the group of slabs in need of urgent replacement.

Table 4. Criteria for assessment of the pavement deterioration degree specific for functional constituents of airfields (EFL)

\begin{tabular}{|c|c|l|}
\hline Status & Grade & Specification \\
\hline Good & $0 \div 10$ & $\begin{array}{l}\text { The pavement has only minor flaws or is } \\
\text { completely free of damage and needs merely } \\
\text { scheduled maintenance. }\end{array}$ \\
\hline Satisfying & $11 \div 25$ & $\begin{array}{l}\text { The pavement has flaws of minor severity that need } \\
\text { merely scheduled maintenance. }\end{array}$ \\
\hline Pufficient & $26 \div 40$ & $\begin{array}{l}\text { The pavement has flaws of minor and medium } \\
\text { severity. Scheduled and more extensive repairs } \\
\text { should be carried out very soon. }\end{array}$ \\
\hline Very poor & $56 \div 70$ & $\begin{array}{l}\text { The pavement has flaws of minor, medium and high } \\
\text { severity which probably entail problems with the } \\
\text { airfield operation. Maintenance jobs should include } \\
\text { scheduled repairs and urgent refurbishment works. }\end{array}$ \\
\hline Serious & $\begin{array}{l}\text { The pavement has flaws that are predominantly of } \\
\text { medium and high severity and lead to substantial } \\
\text { problems with the airfield maintenance and } \\
\text { operation. Intense maintenance works and repairs } \\
\text { are indispensable and very urgent. }\end{array}$ \\
\hline Unsuitable & $86 \div 100$ & $\begin{array}{l}\text { The pavement is seriously damaged and has flaws } \\
\text { mostly of high severity which prevent the airfield } \\
\text { from smooth operation . Prompt repairs are } \\
\text { indispensable. }\end{array}$ \\
\hline & $\begin{array}{l}\text { Deterioration of the pavement surface has reached } \\
\text { the level in which safe avionic operations are no } \\
\text { longer possible. Full refurbishment of the pavement } \\
\text { is a must. }\end{array}$ \\
\hline
\end{tabular}




\section{References}

[1] P. Nita, 2008, „Budowa i utrzymanie nawierzchni lotniskowych”. Wydawnictwo Komunikacji i Łączności. Warszawa; ('Construction and maintenance of airfield pavements', WKiŁ Pubishing House, Warsaw).

[2] System Oceny Stanu Nawierzchni SOSN. Wytyczne stosowania. GDDP, Warszawa 2002; ('SOSN System for Assessment of Pavement Condition. Guidelines for use' GDDP, Warsaw, 2002).

[3] S. Szpinek, 1993, „Koncepcja metody inwentaryzacji stanu uszkodzeń nawierzchni lotniskowej na podstawie komputerowej analizy zdjęć lotniczych". IBDiM, z. 2/93, Warszawa; ('The concept of stocktaking and evaluation of airfield pavement flaws on the basis of computer-aided analysis of aerial photographs', IBDiM, vol. 2/93, Warsaw).

[4] Pakiet: Statistica PL dla Windows. Wyd. StatSoft, Kraków 1994. ('Statistica PL package for Windows', StatSoft, Cracow, 1994).

[5] „Tymczasowe wytyczne kontroli i oceny stanu technicznego nawierzchni lotniskowych". ITWL, Warszawa 1992 r. ('Provisional guidelines for inspection and evaluation of the technical condition demonstrated by airfield pavements', ITWL, Warsaw, 1992).

[6] „System bieżącej oceny stanu technicznego nawierzchni lotniskowych i prognozowanie prac remontowych". ITWL, Warszawa 2002 r. ('System for scheduled assessment of the technical condition demonstrated by airfield pavements and prediction of refurbishment jobs' ITWL, Warsaw, 2002)

[7] M. Wesołowski plus zespół, 2014, „Weryfikacja wskaźników oceny stanu technicznego nawierzchni lotniskowych na podstawie testów na rzeczywistych obiektach. ITWL, Warszawa, (M. WESOŁOWSKI et. al. 'Use of field test results for verification of indices for assessment of the technical condition demonstrated by airfield pavements' ITWL, Warsaw).

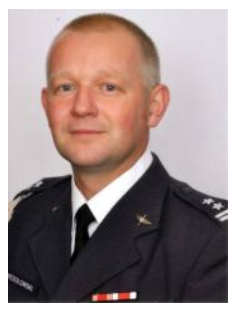

Lieutenant Colonel Mariusz Wesolowski, PhD., Eng. has graduated from the Military University of Technology (WAT) and Technical University of Warsaw. Nowadays, he is the Manager of the Airfield Department at the Air Force Institute of Technology. He has majored in engineering and construction of airfield pavements with further assessment of their technical condition.

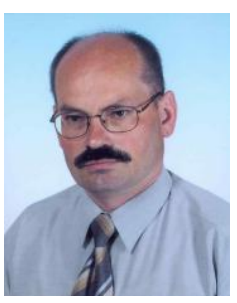

Piotr Barszcz, PhD., Eng., has graduated from the Military University of Technology (WAT). He has majored in topics related to corrosion, reliability, safety and operation of aircrafts. Currently, he is employed as an Assistant Professor at the Air Force Institute of Technology and is involved in projects aimed at development and implementation of a system for management of airfield pavements. 
Assessment of the deterioration degree of airfield pavement functional...

Ocena stopnia zdegradowania nawierzchnii elementów funkcjonalnych lotnisk... 